\title{
Water Use and Crop Coefficients in Sprinkler Irrigated Rice
}

\author{
Antonino Spanu*, Antonio Murtas, Francesca Ballone ${ }^{(\dagger)}$ \\ Dipartimento di Scienze Agronomiche e Genetica Vegetale Agraria, Università di Sassari \\ Via E. de Nicola 9, 07100 Sassari, Italy
}

Received: 8 April 2009. Accepted: 31 May 2009.

\begin{abstract}
Field experiments were carried out during the years 2002, 2004, 2005 and 2006 to analyze water-soil-atmosphere interactions in sprinkler irrigated rice. The research was carried out in Sardinia (39 59' N; $8^{\circ} 40^{\prime}$ E, at altitude 15 m). The cultivars used in the experiments, respectively in 2002 and in 2004-2005-2006, were Irat 212 and Eurosis. In each year cultivars were subjected to the same crop management. Irrigation was applied since the emergence with the sprinkler method, taking into account the loss of water from 'Class A' pan evaporation. Soil water content was monitored at $0.10 \mathrm{~m}$ intervals until 1.00-m depth using a 'Diviner 2000' (Sentek). In 2002 seven irrigation scheduling treatments were compared. In 2004, 2005, 2006 irrigation treatments provided for optimal soil water conditions during the growing season.

In 2002 the results highlighted: 1) 0-0.20 m depth was the most important layer for crop water uptake and the best correlated layer with rice rough yield; 2) the positive relationship between yield and water supply was significant until $6500 \mathrm{~m}^{3} \mathrm{ha}^{-1}$ of water applied. Further seasonal irrigation volumes did not increase significantly yield.

In 2004, 2005 and 2006 the analysis of the soil water balance at different crop phenological stages allowed to estimate crop coefficients (Kc) using the Penman-Monteith equation and the 'Class A' pan evaporation (Kcev).

Kc varied over the three-year period on average from 0.90 to 1.07 and 0.97 , respectively for the emergence-end of tillering, end of tillering-heading and heading-maturing periods, while crop coefficients as a ratio between maximum crop evapotranspiration (ETc) and Epan, Kcev ranged from 0.78 to 0.92 and 0.81 for the same time periods.
\end{abstract}

Key-words: rice, sprinkler irrigation, crop coefficients.

\section{Introduction}

Rice is usually cultivated in anaerobic conditions, as the crop grows well under the submerged conditions created by the basin irrigation method. However, this method requires a huge amount of water, that is variable between 13000 and $20000 \mathrm{~m}^{3} \mathrm{ha}^{-1}$ or even more, depending on pedoclimatic conditions and cultivars (Giardini, 1992; Luppi et al., 2000; Spanu et al., 1989). The high water consumption is mainly attributable to the water lost by soil evaporation (E), by crop transpiration (T) and by deep percolation (D) below the rooting zone consequently to the hydrostatic load of a few saturated centimeters of shallow soil. The amount of water lost by transpiration is the only loss of water that is involved in crop production because transpiration is a driven process for growth and yield components formation. The reduction in $\mathrm{E}$ and $\mathrm{D}$ components is possible through the increase of the irrigation efficiency, which can be achieved through the sprinkler irrigation method. Such method could allow to grow rice in areas with limited water availability and in soils which are not suitable for basin irrigation. It is an alternative method for rice irrigation to save water, but also to simplify crop management, to reduce environmental impact and to make possible the traditional crop rotation for rice.

Many studies have been carried out on the

* Corresponding Author: Tel.: +39 079 229228; Fax: +39 079 229222. E-mail address: tspanu@uniss.it 
physiology and phenology of rice grown in basins, but only a few works (Arf et al., 2000; 2002; 2003) have been conducted on rice irrigated by sprinkler method. Studies are needed, in particular, on the crop yield response to the amount of water applied and to the irrigation interval. The experiments carried out in Sardinia using sprinkler irrigation have highlighted the possibility of reducing water use even to $50 \%$ (Spanu et al., 2002; 2003), without decreasing optimum rice yields.

In order to save water through a rational irrigation scheduling, it is of relevance the calculation of the maximum crop evapotranspiration over the entire growing cycle (ETc) and the crop coefficients related to each phenological phase.

\section{Material and Methods}

\subsection{Site and Soil}

The research was carried out during 2002, 2004, 2005 and 2006 cropping seasons, in Sardinia, at the experimental fields of the University of Sassari (3959' N; 8'40' E, altitude $15 \mathrm{~m}$ ). The soil is a medium clayey textured, Typic Eutric Haplic Fluvisol. Soil chemical properties are characterized by neutral $\mathrm{pH}$, absence of carbonates, low total nitrogen $(0.08 \%)$ and organic carbon $(1.35 \%)$ and by high phosphorus (189.5 ppm as $\mathrm{P}_{2} \mathrm{O}_{5}$ assimilable) and potassium content (249.5 ppm as $\mathrm{K}_{2} \mathrm{O}$ exchangable). Water contents at field capacity and at permanent wilting point were those typical for this type of soil $(\mathrm{FC}=$ $34.5 \%$ volume; $\mathrm{WP}=20.35 \%$ volume $)$.

\subsection{Crop management}

The two cultivars used in the experiments, respectively in 2002 and in 2004-2005-2006, were Irat 212 and Eurosis, which are two mediumearly maturing type cultivars and two of the best yielding cultivars in sprinkler irrigated conditions (Arf et al., 2002; Spanu et al., 2003).

In all the years crop management was consistent with local agronomic practices. The seed bed was prepared by chisel ploughing to a depth of $0.20 \mathrm{~m}$, followed by a secondary tillage with a field cultivator. All plots received a basal application of $45 \mathrm{Kg} \mathrm{ha}^{-1}$ of $\mathrm{N}_{2}, 90 \mathrm{Kg} \mathrm{ha}^{-1}$ of $\mathrm{P}_{2} \mathrm{O}_{5}$ and $50 \mathrm{Kg} \mathrm{ha}^{-1}$ of $\mathrm{K}_{2} \mathrm{O}$ before sowing. Additional nitrogen as $\mathrm{Ca}\left(\mathrm{NO}_{3}\right)_{2}$ was top dressed at mid- tillering and stem elongation at $30 \mathrm{Kg} \mathrm{ha}^{-1}$ each time.

Insect damages were prevented by spraying $40 \mathrm{Kg} \mathrm{ha}^{-1}$ of $7 \%$ - chlopyrifos before sowing.

Weeds were chemically controlled by applying $1250 \mathrm{~g} \mathrm{ha}^{-1}$ of pendimethalin at pre-emergence.

Cultivars were sown on 28 May 2002, 1 June 2004, 12 May 2005 and 10 May 2006 at 500 viable seeds $\mathrm{m}^{-2}$ with a 14-row planter and in plots of $15.7 \mathrm{~m}^{2}$ at $3 \mathrm{~cm}$ depth.

Irrigation of $100 \mathrm{~m}^{3} \mathrm{ha}^{-1}$ was applied until emergence with sprinkler method every 2-3 days depending on the meteorological data.

\subsection{Treatments and design}

The experiment was a complete randomized block design with four replications.

Irrigation was applied during the emergencestem elongation period when the daily Epan sum reached $20 \mathrm{~mm}$, while during the stem elongation-maturity period when the daily Epan sum reached $30 \mathrm{~mm}$.

Seven irrigation scheduling treatments were compared in 2002: treatments V1, V2, V3, V4 and V5, characterized by a difference in the time interval between irrigation events resulting from adjusting the Epan with different empirical coefficients; treatment VM (medium stressed), in which irrigation was delayed of 2-3 days compared to V1; treatment VS in which irrigation was applied when leaf rolling was observed on the last emerged leaves.

In the three seasons, $2004-2006$, the object of the study was to estimate only the rice crop coefficients using the data from four replications.

\subsection{Measurements}

Water content was recorded for each replication in 2004, 2005, 2006, whereas only for two replications in 2002.

Soil water content was monitored at $0.10 \mathrm{~m}$ intervals until $1.00 \mathrm{~m}$ depth approximately every day using a "Diviner 2000" (Sentek).

In 2004, 2005 and 2006 measurements were made in order to determine in optimal water availability conditions the ratio $(\mathrm{Kc})$ between maximum crop evapotranspiration and reference evapotranspiration (ETo) estimated by Penman-Monteith method and Kcev as the ratio between maximum crop evapotranspiration and Class A "pan" evaporation (Epan).

Irrigation was delivered every time soil mois- 
ture in the $0-0.40 \mathrm{~m}$ layer decreased below the field capacity value determined in the field.

Crop evapotranspiration (ETc) during the growing season was calculated using the data provided by the "Diviner 2000" and according to the soil water balance equation:

$$
\mathrm{ET}=\mathrm{P}-(\mathrm{R}+\mathrm{U}) \pm \Delta \mathrm{W}
$$

where:

$\mathrm{ET}=$ loss of water from the soil by evaporation and from the crop by transpiration;

$\mathrm{P}=$ irrigation plus effective rainfall (USDA, 1967);

$\mathrm{R}=$ surface runoff;

$\mathrm{U}=$ water that percolates downward from the root zone or, in this experiments, from the deepest layer monitored by the probe;

$\Delta \mathrm{W}=$ rate of moisture variation in the $0-1.00$ $\mathrm{m}$ layer.

In the 4-year experiments soil moisture content did not vary below the $0.70 \mathrm{~m}$ depth as a consequence of the absence of percolation, which was therefore considered absent. On the other hand, as result of the flat soil surface and of the low irrigation intensity also $\mathrm{R}$ component was assumed to be negligible. Therefore, under optimal soil water condition, the maximum crop evapotranspiration can be expressed by the following equation:

$$
\mathrm{ETc}=\mathrm{P} \pm \Delta \mathrm{W}
$$

Along the growing cycle, the main phenological stages were recorded. In $0.28 \mathrm{~m}^{2}$ sam- pling areas plant number at emergence, plant height at flag leaf auricles and at panicle base levels, total plant height, fertile and sterile kernels per panicle were recorded.

Grain sample was taken to determine rice head yield.

\section{Results and discussion}

\subsection{Weather - Year 2002}

Weather records were obtained from a meteorological station located a few kilometres from the field.

Minima and maxima temperatures were close to their long term averages. In the midgrowing season the lowest minimum temperature $\left(24^{\circ} \mathrm{C}\right)$ was slightly higher than its long term average, while it was lower at the beginning and at the end of the growing season (respectively, $7{ }^{\circ} \mathrm{C}$ and $8{ }^{\circ} \mathrm{C}$ ). The highest maxima temperatures were recorded between tillering and stem elongation and ranged between 37.0 and $40.1{ }^{\circ} \mathrm{C}$. Generally, temperatures were favourable along all developmental stages.

The excessive rainfall markedly increased air humidity, which occasionally reached values below $40 \%$.

Precipitation differed from the long term average, with $200 \mathrm{~mm}$ falling during the sowing-harvest period. Rainfall between April and first decade of May $(110 \mathrm{~mm})$ led soil to field capacity.

Figure 1 shows reference evapotranspiration

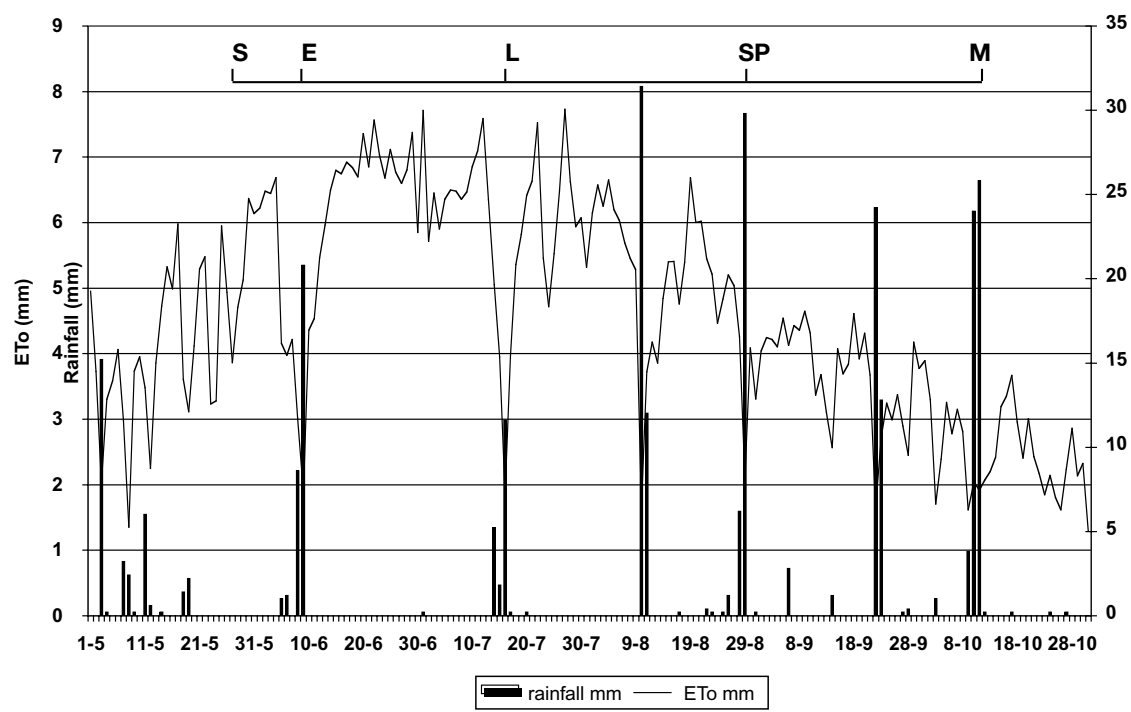

Figure 1. Reference evapotranspiration (ETo) and rainfall trend recorded from May to October 2002. (S: sowing; E: emergence; L: stem elongation; SP: heading; M: physiological maturity). 


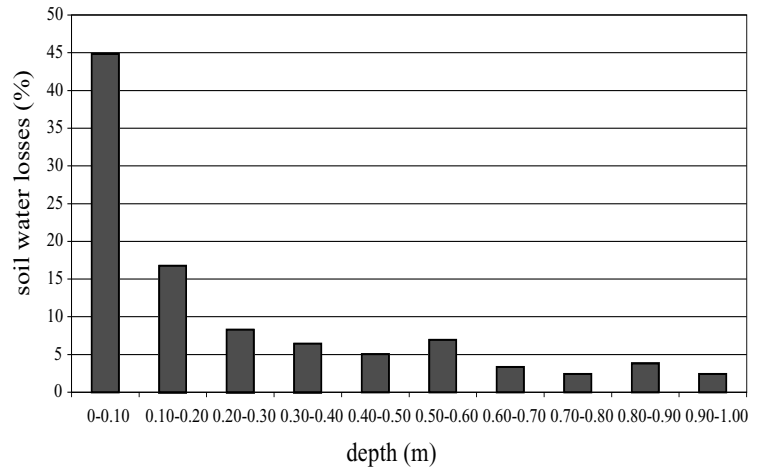

Figure 2. Water losses at different soil depths observed in V5 treatment from 16 July to 14 October. Each point corresponds to the average between 2-replication values.

(ETo) values calculated according to PenmanMonteith equation and precipitations for the period from May to October. The highest ETo values coincided with the period of highest drought, reaching maxima values $\left(7.7 \mathrm{~mm} \mathrm{~d}^{-1}\right)$ at the beginning and at the end of July, while minima values were observed when rainfall occurred. Over the sowing-maturing period ETo was $694 \mathrm{~mm}$ and rainfall $267.6 \mathrm{~mm}$.

Figure 2 reports the average loss of water at $0.10 \mathrm{~m}$ intervals until $1.00 \mathrm{~m}$ depth. Values refer to the most irrigated V5 treatment and to the period from 16 July to 14 October. The highest loss of water occurred in the $0-0.40 \mathrm{~m}$ layer ( $76 \%), 45 \%$ being lost in the $0-0.10 \mathrm{~m}$ layer as a consequence of the highest root density and evapotranspiration rate. The loss of water was $17 \%$ in the layer $0.10-0.20 \mathrm{~m}$ and $8 \%, 6 \%$, re- spectively, in the $0.20-0.30 \mathrm{~m}$ and $0.30-0.40 \mathrm{~m}$ layers.

\subsection{Irrigation scheduling and soil water content variation}

Seasonal irrigation volumes ranged between 3916 (VS treatment) and $7794 \mathrm{~m}^{3} \mathrm{ha}^{-1}$ (V5 treatment) and were applied respectively, with 18 and 37 irrigations. The treatments VM, V1, V2, V3, V4 were irrigated, respectively, with water volumes of 5082, 5735, 6181, 6677, $7259 \mathrm{~m}^{3} \mathrm{ha}^{-1}$ applied with 23, 27, 29, 31, 34 irrigations.

Figures $3,4,5$ show soil water content variation over the 2002 growing season as a function of the irrigation scheduling. Data were available at $0.10 \mathrm{~m}$ intervals until $1.00 \mathrm{~m}$ depth, but figures report the variation in soil water content for the layers $0-0.10,0.10-0.20,0.20-0.30$, $0.30-0.40,0.40-1.00 \mathrm{~m}$, since the averaged value over the $0-40 \mathrm{~cm}$ is the most important layer for crop water uptake. To show the most significant results, only data from treatments VS and V5 are reported in the figures. Whereas, treatments V2, V3, V4 are not shown because similar in yields to treatment V5.

Figure 3 presents the variation in soil water content relative to treatments VS. Note that all the soil profile was interested to variation in soil water content, including layer $0.40-1.00 \mathrm{~m}$ for a short time.

Figure 4 shows the variation in soil water content for treatment V5. All profile was constantly under conditions of high soil moisture, at about $47 \%$ and rarely reached $40 \%$.

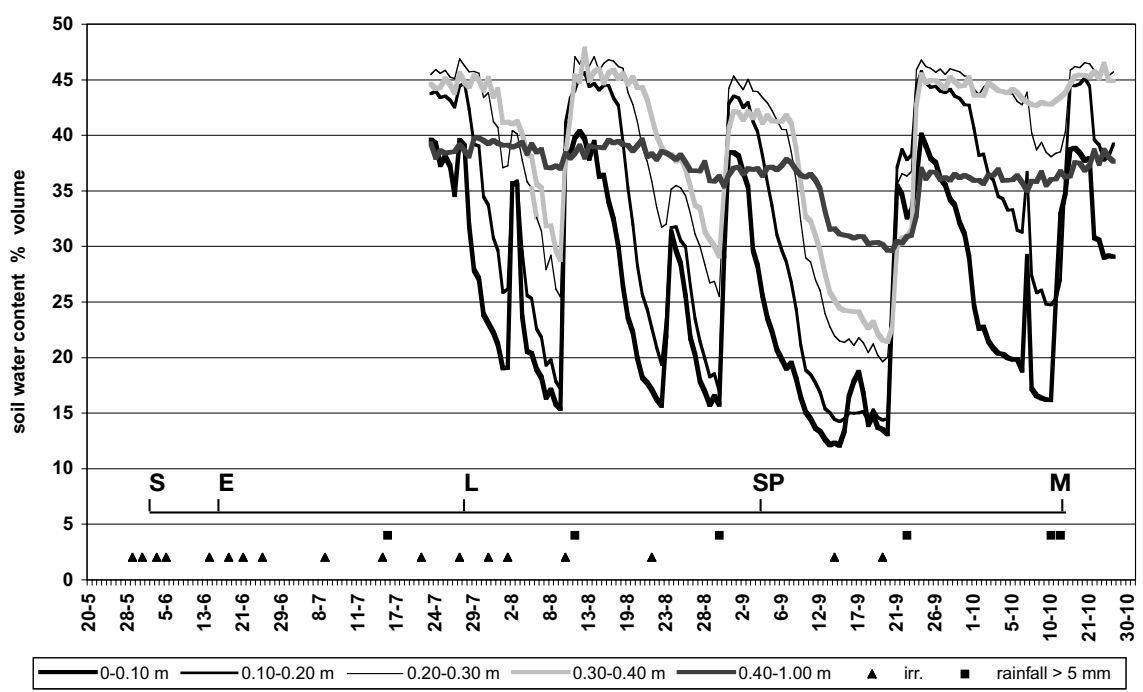

Figure 3. Variation in soil water content for different layers of the treatment VS, from stem elongation to physiological maturity in the 2002. (S: sowing; E: emergence; L: stem elongation; SP: heading; M: physiological maturity). 

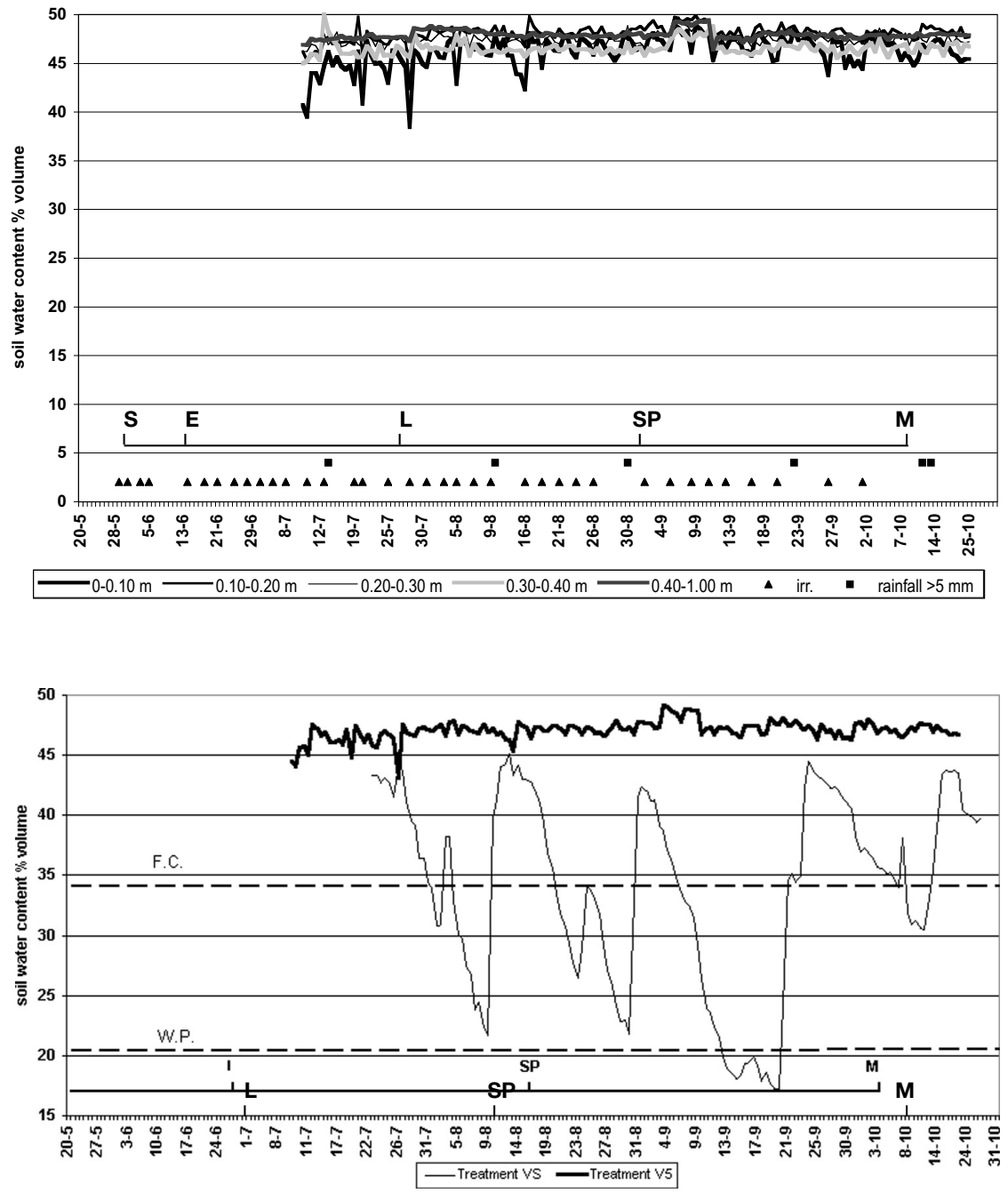

Figure 4. Variation in soil water content for different layers of the treatment V5, from stem elongation to physiological maturity in the 2002 . (S: sowing; E: emergence; L: stem elongation; SP: heading; M: physiological maturity).

Figure 5. Variation in soil water content of the layer 0 $0.40 \mathrm{~m}$ for treatments VS and V5, from stem elongation to physiological maturity in the 2002. (L: stem elongation; SP: heading; M: physiological maturity; FC: field capacity; WP: wilting point).

In treatment VM only the upper soil layers $(0-0.40 \mathrm{~m})$ showed variation in soil water content. At deeper soil layer $(40-100 \mathrm{~cm})$ variations were low and scarcely affected yield.

In treatments V1, V2, V3, V4 only the 0-0.10 $\mathrm{m}$ layer was influenced by rainfall events. Deeper layers were slightly affected by rainfall, but the response to rain increased if periods between consecutive irrigations were reduced.

Averaged variation in soil water content of the layer mainly interested $(0-0.40 \mathrm{~m})$ in crop water uptake is shown in Figure 5 for treatments VS and V5.

The study of soil water variation highlights that soil water content in treatment VS reached the wilting point on several occasions over the growing season. Such severe water shortage oc- curred for a short time during the heading phase, while for a longer period during the early maturing phase. Stress conditions determined shorter neck nodes, lower storage reserves accumulation and a consequent decreased in yield (Tab. 1). Vice versa in treatment V5 soil water content did not reach values below the maximum field capacity over the whole growing season.

Variation in soil water content of the $0-0.40$ $\mathrm{m}$ layer differed between the treatments VM and VS. Values below field capacity (between $80 \%$ and $43 \%$ of the available soil water) were recorded in the last twenty days of September.

The soil water content of the treatments V1, V2, V3, V4 and VM varied gradually and according to irrigation scheduling (data not 
Table 1. Bio-morphological parameters for the compared treatments.

\begin{tabular}{lcccccc}
\hline Treatments & $\begin{array}{c}\text { Sowing } \\
\text { Heading } \\
\text { days }\end{array}$ & $\begin{array}{c}\text { Sowing } \\
\text { maturity } \\
\text { days }\end{array}$ & $\begin{array}{c}\text { Total height } \\
\text { plant } \\
\mathrm{cm}\end{array}$ & $\begin{array}{c}\text { Yield (13\% grain } \\
\text { moisture content) } \\
\text { tha }^{-1}\end{array}$ & $\begin{array}{c}\text { 1000 Kernel } \\
\text { Weight } \\
\text { g }\end{array}$ & $\begin{array}{c}\text { Rice head } \\
\text { yield } \\
\%\end{array}$ \\
\hline V1 & $96.5 \mathrm{a}$ & $141.5 \mathrm{~b}$ & $78.2 \mathrm{a}$ & $7.23 \mathrm{~b}$ & $24.0 \mathrm{~b}$ & $67.7 \mathrm{ab}$ \\
V2 & $94.5 \mathrm{~b}$ & $139.5 \mathrm{c}$ & $77.3 \mathrm{a}$ & $7.64 \mathrm{ab}$ & $24.6 \mathrm{ab}$ & $68.2 \mathrm{ab}$ \\
V3 & $93.5 \mathrm{~b}$ & $139.0 \mathrm{~cd}$ & $83.2 \mathrm{a}$ & $7.97 \mathrm{a}$ & $25.0 \mathrm{a}$ & $70.8 \mathrm{a}$ \\
V4 & $93.0 \mathrm{~b}$ & $138.5 \mathrm{~d}$ & $80.6 \mathrm{a}$ & $8.04 \mathrm{a}$ & $24.6 \mathrm{ab}$ & $68.2 \mathrm{ab}$ \\
V5 & $92.5 \mathrm{~b}$ & $138.3 \mathrm{~d}$ & $79.5 \mathrm{a}$ & $7.90 \mathrm{a}$ & $25.2 \mathrm{a}$ & $69.8 \mathrm{ab}$ \\
VS & $97.0 \mathrm{a}$ & $145.0 \mathrm{a}$ & $66.0 \mathrm{~b}$ & $4.10 \mathrm{~d}$ & $23.0 \mathrm{c}$ & $67.0 \mathrm{~b}$ \\
VM & $96.0 \mathrm{a}$ & $141.0 \mathrm{~b}$ & $73.8 \mathrm{a}$ & $5.94 \mathrm{c}$ & $24.5 \mathrm{ab}$ & $68.0 \mathrm{ab}$ \\
\hline
\end{tabular}

Means sharing the same letter do not differ significantly from one another (Duncan test at $\mathrm{P} \leq 0.05$ ).

shown). In particular, treatment V1 showed values below field capacity only in the early phase of monitoring, while later values ranged between field capacity and saturation. Treatments V2, V3, V4 showed similar soil water content values, close to field capacity, which reflected the highest yield but not significantly different among them.

\subsection{Development and Yield}

Table 1 shows productive and qualitative biomorphological parameters.

The limited water availability affected the growing season duration, lengthening the phenological phases and negatively influencing all the considered parameters.

Figure 6 shows the relationship between the crop yield response value, averaged over all treatments, to irrigation treatments (seasonal irrigation volumes) yield significantly increased up to a seasonal irrigation volume of $6500 \mathrm{~m}^{3} \mathrm{ha}^{-1}$.

The relationship between yield and percent-

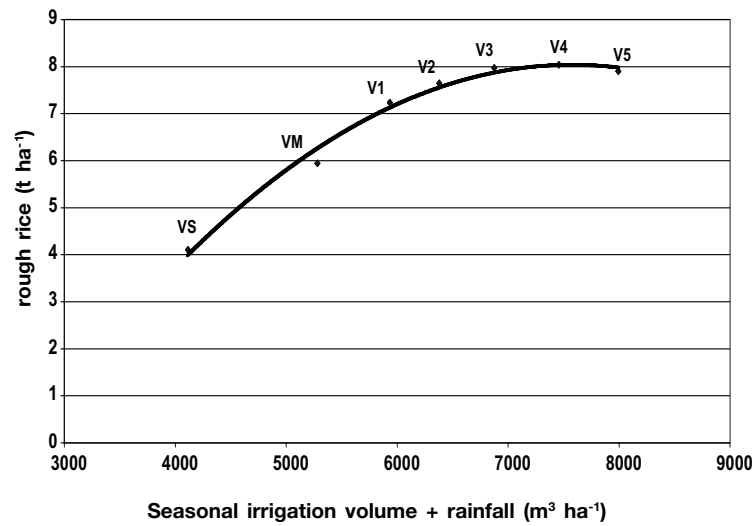

Figure 6. Rice yield versus seasonal irrigation volume. Each point corresponds to the average of 4 replications. age of soil water content is reported in Figure 7. The strongest association with yield $(\mathrm{r}=$ $\left.0.85^{* *}\right)$ was found considering the soil water content (\%) of the $0-0.20 \mathrm{~m}$ layer, probably as a consequence of the greater proportion of roots in this layer. In fact a previous experiments comparing 29 sprinkler-irrigated rice cultivars showed that the root density was higher in the $0-0.20 \mathrm{~m}$ layer $\left(30 \mathrm{~cm} \mathrm{~cm}^{-3}\right)$ and decreased to less than $10 \mathrm{~cm} \mathrm{~cm}^{-3}$ in deeper layers (Spanu et al., 2004).

\subsection{Weather conditions relative to the period 2004-2006}

The maxima and minima temperatures for 2004 season were close to the typical pattern. The highest temperature value was $40{ }^{\circ} \mathrm{C}$ at the beginning of July. Temperature values were close to $37{ }^{\circ} \mathrm{C}$ during several days until the first decade of September. Minimum temperature after sowing reached $11{ }^{\circ} \mathrm{C}$ and later ranged between 14 and $24{ }^{\circ} \mathrm{C}$. Daily average minimum

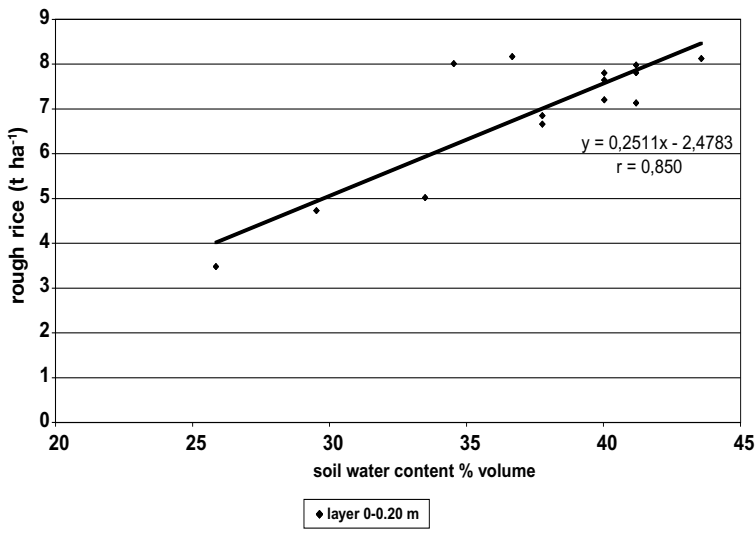

Figure 7. Relationship between rough rice yield and percentage of soil water content observed in the layer $0-0.20 \mathrm{~m}$. 


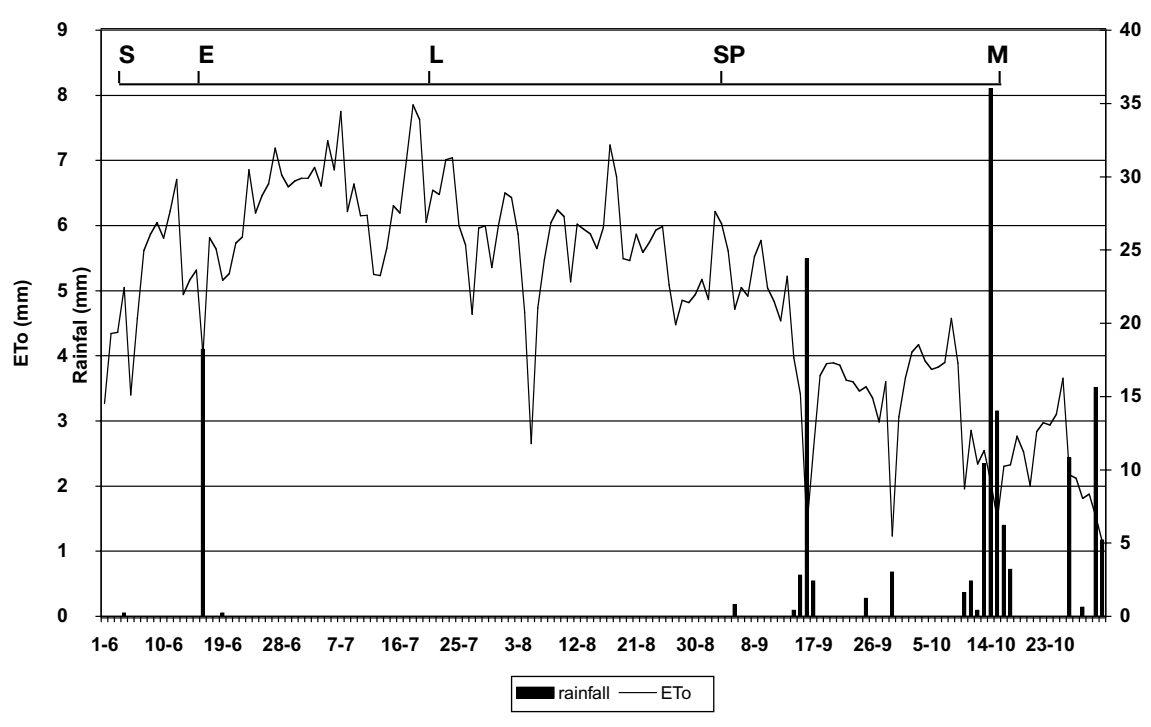

Figure 8. Reference evapotranspiration $\left(\mathrm{ET}_{\mathrm{o}}\right)$ and rainfall trend recorded from (S) to $(\mathrm{M})$ in 2004. (S: sowing; E: emergence; L: stem elongation; SP: heading; M: physiological maturity). temperature during ripening was close to $10^{\circ} \mathrm{C}$.

Minimum air relative humidity was on average $34 \%$, ranging between $14 \%$ and $78 \%$.

Figure 8 shows as varied daily reference evapotranspiration (ETo) values calculated by the Penman-Monteith equation and daily rainfall. The highest daily ETo values $(7.8 \mathrm{~mm})$ were recorded in July, while the lowest values (less than $2 \mathrm{~mm}$ ) at the end of the growing season in correspondence of rainy or cloudy days. Most of the values were between 5 and $6.5 \mathrm{~mm}$. The cumulated ETo from sowing to maturity was 715 $\mathrm{mm}$.

Precipitations fell mainly at emergence (18 $\mathrm{mm}$ ) and during the end of the season without affecting the ripening phase.

Maximum temperature pattern for 2005 was similar to 2004 , if some high values were neglected. Also minima temperatures did not differ from typical values, ranging between 15 and $24{ }^{\circ} \mathrm{C}$ for the greatest part of the experiment.

Minimum air relative humidity did not differ from the value recorded in 2004. Maxima and minima values were, respectively, 88 and $12 \%$.

In Figure 9 ETo and rainfall values for 2005 are reported. Mean values of ETo varied from 4 to $6 \mathrm{~mm}$ and decreased at the beginning and at the end of the season. The highest values (7.8

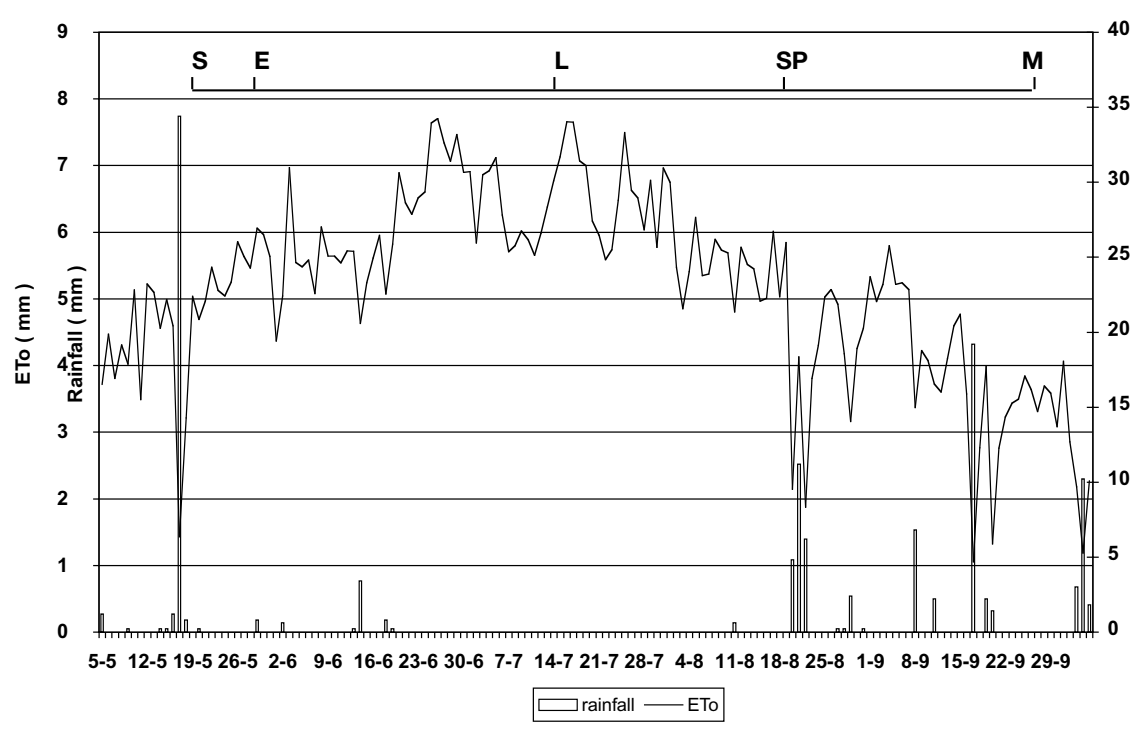

Figure 9. Reference evapotranspiration $\left(\mathrm{ET}_{\mathrm{o}}\right)$ and rainfall trend recorded from (S) to $(\mathrm{M})$ in 2005. (S: sowing; E: emergence; L: stem elongation; SP: heading; M: physiological maturity). 


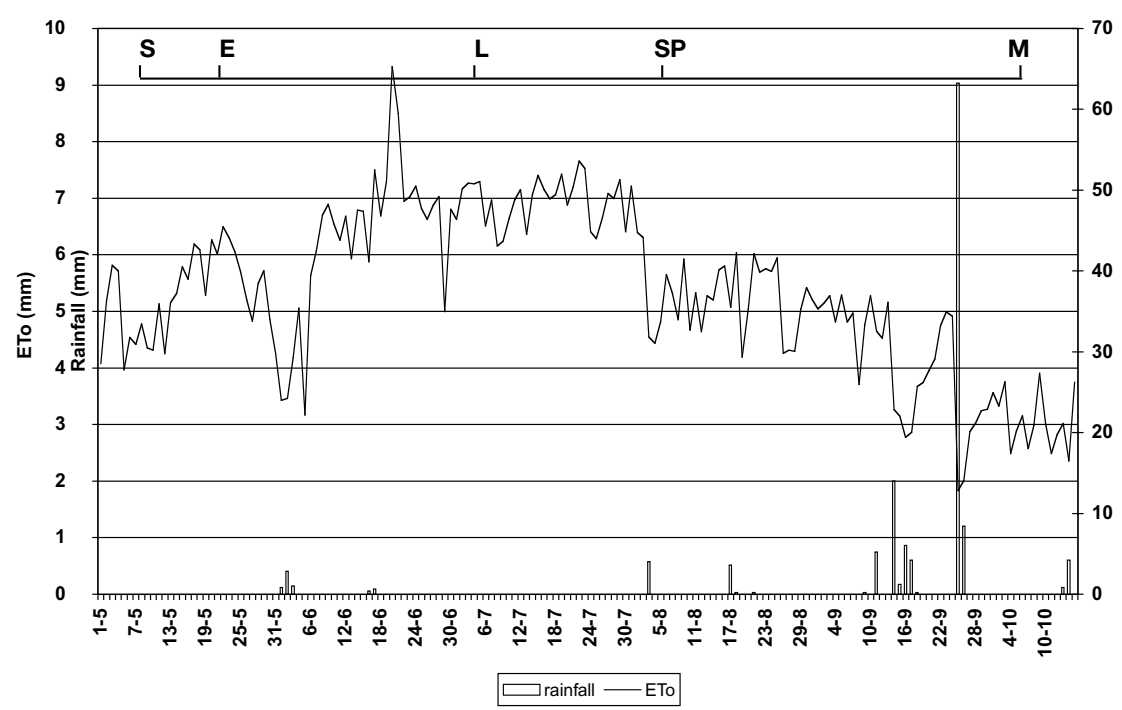

Figure 10. Reference evapotranspiration $\left(\mathrm{ET}_{\mathrm{o}}\right)$ and rainfall trend recorded from (S) to $(\mathrm{M})$ in 2006. (S: sowing; E: emergence; L: stem elongation; SP: heading; M: phyisiological maturity). $\mathrm{mm}$ ) were recorded at the end of June and in July. The cumulated ETo from sowing to maturity was $736 \mathrm{~mm}$.

May rainfall favoured seedling emergence and increased the soil water reserves; August and September rainfall increased the amount of soil water available to the crops without hindering the harvest.

Maxima temperatures for 2006 were higher than the long term average ones and varied from $36{ }^{\circ} \mathrm{C}$ to $40{ }^{\circ} \mathrm{C}$ between heading and maturing phases. Whereas the lowest temperatures varied from 17 and $21{ }^{\circ} \mathrm{C}$ at the beginning of the growing season to $18{ }^{\circ} \mathrm{C}$ at later stages.

Figure 10 shows ETo and rainfall pattern for 2006. ETo values were on average 5.5, 7.0 and $6.5 \mathrm{~mm}$, respectively, at the beginning, in the middle and at the end of the growing season. Seasonal cumulated ETo was $837 \mathrm{~mm}$. Total seasonal rainfall was $121.2 \mathrm{~mm}$ and was mainly concentrated in September.

\subsection{Irrigation volumes and soil water content variations}

Monthly irrigation volumes differed as a consequence of the different monthly rainfall and temperature pattern, while seasonal irrigation volumes were similar over the three-year period. In fact seasonal irrigation volumes in 2004, 2005 and 2006 were 6678, 6774 and $6928 \mathrm{~m}^{3}$ ha ${ }^{1}$ respectively. Figures 11, 12, 13, show soil water content variation averaged for the layer $0-0.40$ m, respectively for 2004, 2005 and 2006.
In 2004 soil water content dropped below field capacity at the beginning of the growing season, probably as a consequence of the high temperatures during the previous year and of the scarce rainfall from autumn 2003 to winter 2004, which did not contribute to recharge soil water content.

In 2005 and 2006 soil moisture was mostly above field capacity, except for only a few days in the middle of the growing season.

\subsection{Phenological phases, yield and its compo- nents}

The crop parameters observed during the three years of research did not differ significantly. The duration of the periods from sowing to heading and from sowing to maturity were on average, respectively, 97 and 138 days. Total plant height was on average $70 \mathrm{~cm}$. Yield at $13 \%$ moisture, 1000 kernel weight and rice head were on average, respectively, $8.6 \mathrm{t} / \mathrm{ha}, 25.0 \mathrm{~g}$ and $65 \%$.

\subsection{Crop coefficients estimated over the period 2004-2006}

The crop coefficients $\mathrm{Kc}$ were calculated as a ratio between maximum crop evapotranspiration (ETc) and reference evapotranspiration (ETo) computed with the Penman-Monteith equation: $\mathrm{Kc}=\mathrm{ETc} / \mathrm{ETo}$; the crop coefficients Kcev as a ratio between ETc and the Class A 'pan' evaporation Kcev = ETc / Epan.

The maximum crop evapotranspiration was determined in non-limited water conditions, tak- 

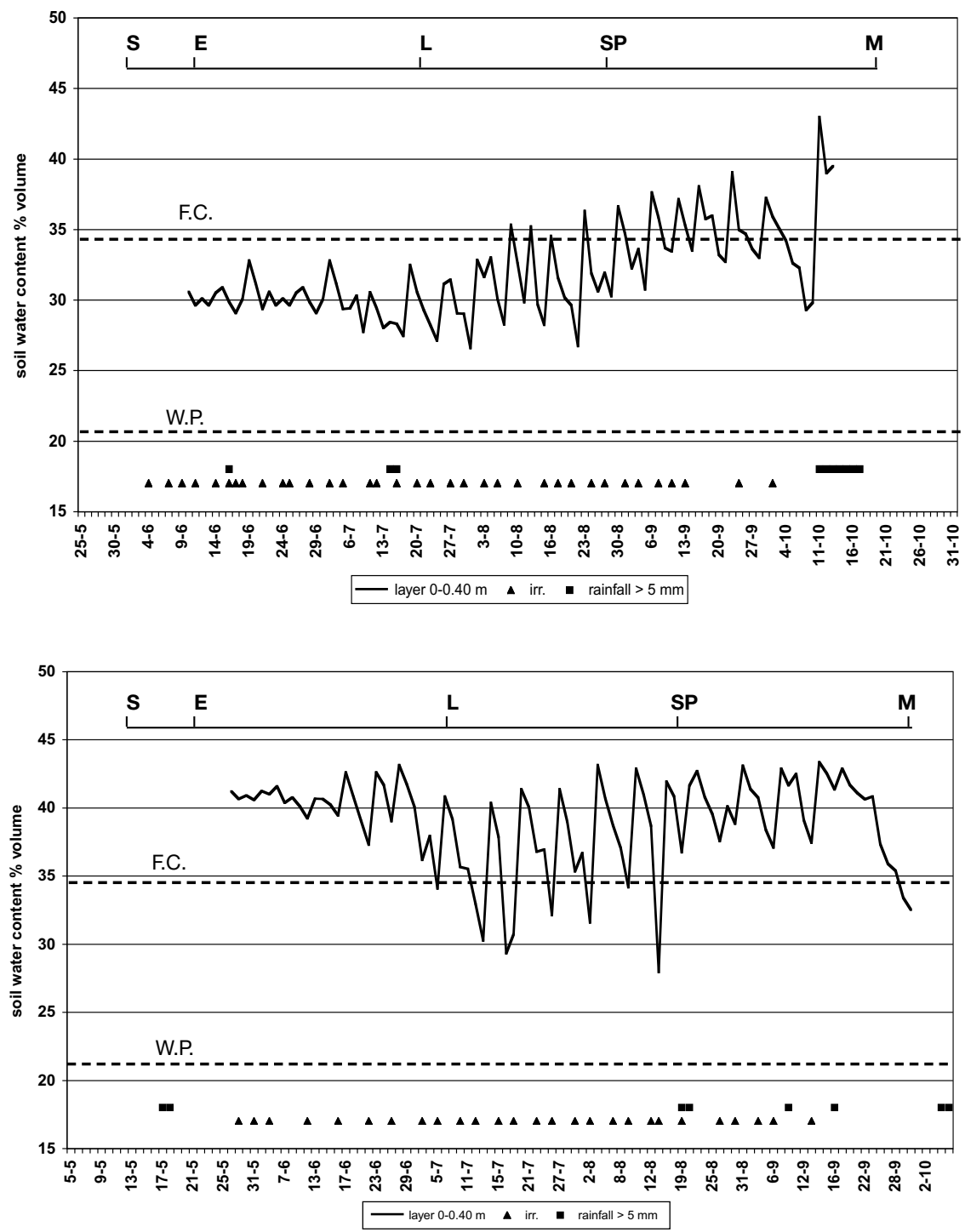

Figure 11. Soil water content variation in the layer $0-0.40$ $\mathrm{m}$, rainfall and irrigation timing for (S) to (M) in 2004. (S: sowing; E: emergence; L: stem elongation; SP: heading; M: physiological maturity; FC: field capacity; WP: wilting point).

Figure 12. Soil water content variation in the layer $0-0.40$ $\mathrm{m}$, rainfall and irrigation timing for (S) to (M) in 2005. (S: sowing; E: emergence; L: stem elongation; SP: heading; M: physiological maturity; FC: field capacity; WP: wilting point).

ing into account precipitation, irrigation, water losses until $1.00 \mathrm{~m}$ and assuming negligible the water storage and percolation below $1.00 \mathrm{~m}$ depth. This assumption was supported by the uniform soil content pattern of the layer 0.90$1.00 \mathrm{~m}$ (Fig. 14).
$\mathrm{Kc}$ and Kcev were determined at different crop stages: a) from emergence to the end of tillering; b) from the end of tillering to heading; c) from heading to maturity.

Kc values for the three-year period are reported in Table 2. The analysis of variance in-

Table 2. Crop coefficients (kc=ETc/ETo) values obtained on rice crop during three years research (2004-2005-2006), where ETc and Eto are, respectively, Crop maximum Evapotranspiration and Reference Evapotranspiration.

\begin{tabular}{lcccc}
\hline Year & Emergence-end of tillering & End of tillering-heading & Heading-maturing & Total growing period \\
\hline 2004 & 0,88 & 1,06 & 0,94 & $0,96 \mathrm{a}$ \\
2005 & 0,88 & 1,21 & 0,97 & $1,00 \mathrm{a}$ \\
2006 & 0,94 & 0,94 & 1,00 & $0,96 \mathrm{a}$ \\
Mean & $0,90 \mathrm{~b}$ & $1,07 \mathrm{a}$ & $0,97 \mathrm{~b}$ & 0,97 \\
\hline
\end{tabular}

Heach value correspond to the average over 4-replication. Means followed by the same letter are not significantly different at $\mathrm{P} \leq 0.01$ 

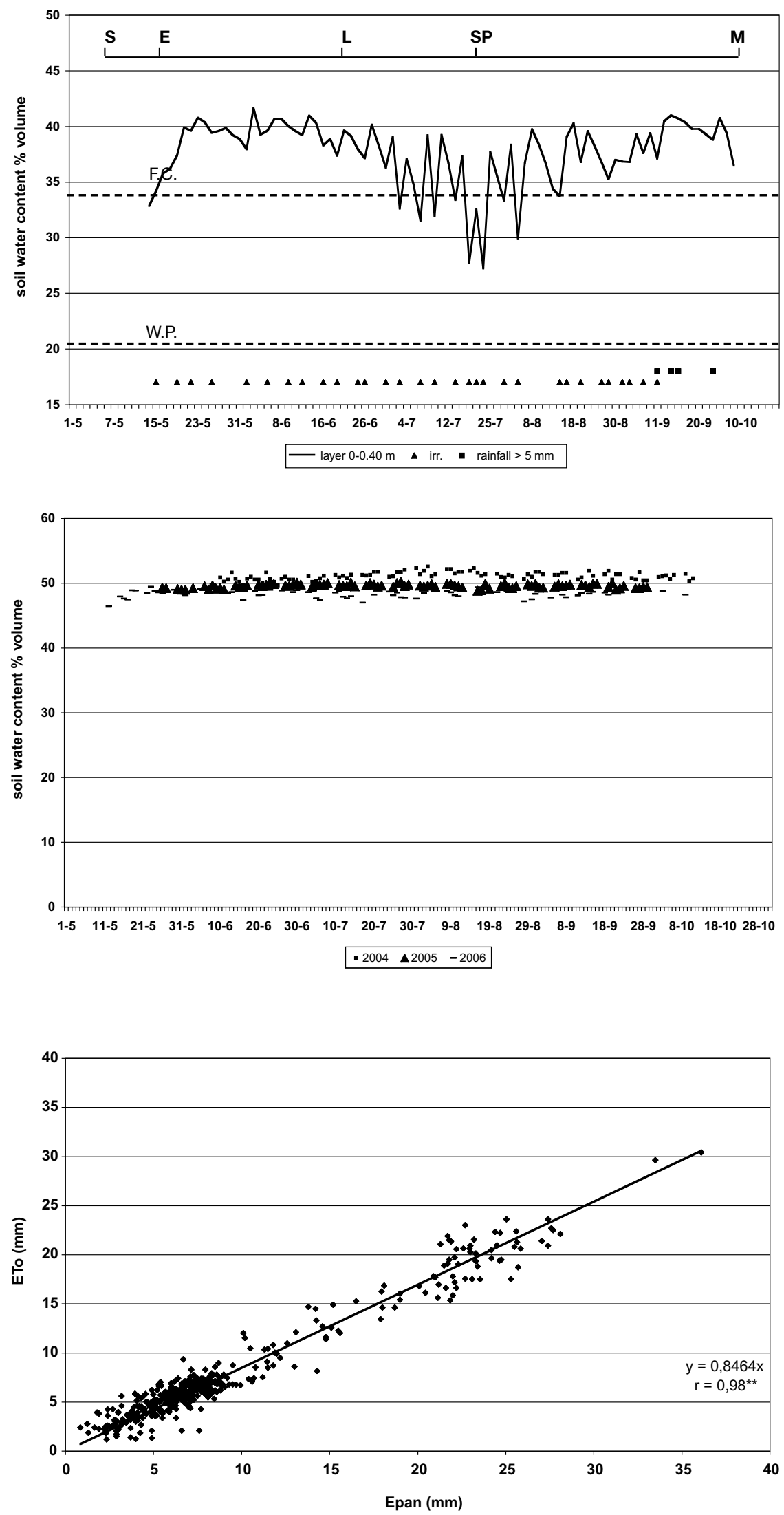

Figure 13. Soil water content variation in the layer $0-0.40$ $\mathrm{m}$, rainfall and irrigation timing for (S) to (M) in 2006. (S: sowing; E: emergence; L: stem elongation; SP: heading; M: physiological maturity; FC: field capacity; WP: wilting point).

Figure 14. Averaged soil water content variation for the layer 0.90-1.00 m. Each point corresponds to the average over 4-replication values.

Figure 15. Relationship between values of Class A 'pan' evaporation (Epan) and evapotranspiration $\left(\mathrm{ET}_{\mathrm{o}}\right)$. ETo was calculated with PenmanMonteith metod. 
Table 3. Crop coefficients $(\mathrm{kcev}=\mathrm{ETc} / \mathrm{Epan})$ values obtained on rice crop during three years research (2004-2005-2006) where ETc and Epan are, respectively, Crop maximum Evapotranspiration and class "A" pan evaporation.

\begin{tabular}{lcccc}
\hline Year & Emergence-end of tillering & End of tillering-heading & Heading-maturing & Total growing period \\
\hline 2004 & 0,75 & 0,89 & 0,82 & $0,82 \mathrm{~b}$ \\
2005 & 0,74 & 0,99 & 0,87 & $0,85 \mathrm{a}$ \\
2006 & 0,85 & 0,87 & 0,76 & $0,83 \mathrm{~b}$ \\
Mean & $0,78 \mathrm{~b}$ & $0,92 \mathrm{a}$ & $0,81 \mathrm{~b}$ & 0,83 \\
\hline
\end{tabular}

Each value correspond to the average over 4-replication. Means followed by the same letter are not significantly different at $\mathrm{P} \leq 0.01$.

dicated the absence of significant differences in $\mathrm{Kc}$ values between individual years. On the contrary, Kc values were significantly different among the crop stages. Therefore, the averaged long term Kc value for each crop stage was considered.

Figure 15 reports the significant relationship $\left(\mathrm{r}=0.98^{* *} ; \mathrm{n}=448\right)$ between the Class A 'pan' evaporation (Epan) and the daily reference evapotranspiration (ETo) estimated by Penman-Monteith method.

Data from field experiments located in S. Lucia during the period 2002-2006 were used to analyze Class A 'pan' evaporation and ETo. The line was forced through the origin and the slope was equal to 0.846 . With a few exceptions, evaporation and ETo values higher than $9 \mathrm{~mm}$ represented the sum of several consecutive days.

Table 3 shows Kcev values. Kcev differences were significant among years, but the long term mean was considered because differences were on average small and lower than the precision of the probe used to determine soil water content.

\section{Conclusions}

From the present experiments conducted on a representative rice area of Central Sardinia the following conclusions can be drawn:

- The sprinkler irrigation method clearly may lead to agronomic and environmental benefits, but also to economical advantages as important decreases in water consumption $(\sim$ $50 \%$ ) can be obtained without a decrease in rice yields.

- The relationship between rice rough yield and seasonal water supply, with regards to the cultivar Irat 212, showed that yields can be increased until water supply reached 6500 $\mathrm{m}^{3} \mathrm{ha}^{-1}$ and that further irrigation volumes were not able to bring convenient increases in yields.

- Kc long term values varied from 0.90 to 1.07 and 0.97 , respectively for the emergence-end of tillering, end of tillering-heading and heading-maturity periods. The Kc value for the first period was influenced by irrigation interval, which in turn depends on the soil type. In this work the Kc value can be considered reliable even for the other rice cultivation areas of Central Sardinia where this study was carried out.

- As a consequence of the strong relationship between ETo and the Class A 'pan' evaporation (Epan) data, Kcev values can be considered as equivalent to $\mathrm{Kc}$ values.

- The Kc and Kcev values calculated through this experiment are average values for the reference periods and are therefore suited for an a priori evaluation of the water requirements of sprinkler irrigated rice, but not for scheduling irrigation. A correct irrigation scheduling has to be based on daily values of Kc and Kcev, which can only be obtained through lysimeter-based studies.

\section{References}

Arf O., Ferreira Rodrigues R.A., Eustàquio de Sà M., Costa Crusciol C.A. 2000. Influência da época de semeadura no comportamento de cultivares de arroz irrigado por aspersão em selvíria, MS. Pesquisa Agropecuaria Brasileira, Vol. 35, 10:1967-1976.

Arf O., Ferreira Rodrigues R.A., Eustàquio de Sà M., Costa Crusciol C.A., Cesar dos Reis Pereira J. 2002. Preparo do solo, irrigacão por aspersão e rendimento de engenho do arroz de terras altas. Scientia Agricola, Vol. 59, 2:321-326.

Arf O., Ferreira Rodrigues R.A., Costa Crusciol C.A., Eustàquio de Sà M., Buzetti S. 2003. Manejo do solo e adbução nitrogenada para cultivares de arroz de terras altas irrigados por aspersão. Scientia Agricola, Vol. 60, 2:345-352. 
Giardini L. 2002. Agronomia generale, ambientale e aziendale. Pàtron Editore, Bologna, 318-319.

Luppi G., Finassi A., Cavallero A. 2000. Riso (Oryza sp. pl.). In: Baldoni R., Giardini L. (eds.): Coltivazioni Erbacee - Cereali e Proteaginose, 244-284. Pàtron Editore, Bologna.

Spanu A., Pruneddu G., Deidda M. 1989. Primi risultati sulla coltivazione del riso (Oryza sativa L.) irrigato per aspersione. Rivista di Agronomia, 6:378-384.

Spanu A., Murtas A. 2002. Coltivazione del riso con irrigazione per aspersione. L'Informatore Agrario, 7:33-36.
Spanu A., Murtas A., Ledda L., Ballone F., Testoni A., Ardu A. 2003. Riso: confronto tra nuove varietà irrigate per aspersione. L'Informatore Agrario, 12:53-56.

Spanu A., Murtas A., Ledda L., Ballone F. 2004. Root system development in flooded and sprinkler irrigated rice cultivars. Proceedings of the conference: Challenges and opportunities for sustainable ricebased production systems, 13-15 September, Torino, Italy.

USDA (Soil Conservation Service), 1967. In FAO Irrigation and Drainage, paper n. 25, Effective Rainfall in Irrigated Agriculture. 